\title{
Differences in student blood pressure before and after consuming fish oil
}

\author{
Eddie Nagadi*, Edeh Roletta Haroen*, Tuty Sutini Richata* \\ *Department of Oral Biology Faculty of Dentistry Universitas Padjadjaran
}

\begin{abstract}
Introducion: Fish oil is especially believed to be able to decrease blood pressure. This is caused by omega-3 fatty acid that contained in fish oil. This study was implemented to analyzed the difference in student's blood pressure before and after consuming fish oil. Methods: This study was performed as an experimental research, using pair measurement of the effect of fish oil on blood pressure before and after consuming fish oil. The samples were 30 students aged 18 - 25 years old in Faculty of Dentistry, UNPAD. The amount of fish oil that had to consume were 4 grams per day. Blood pressure measured by the auscultatory-palpation method. Results: The average difference in systolic pressure before and after consuming fish oil is $-5,7111 \mathrm{mmHg}$, while that for diastolic pressure is $-4,0889 \mathrm{mmHg}$. Statistical analysis $t$-test student with $a=0.05$, shows that the value of $t$ for systolic pressure is $-12,9389$, while that for diastolic pressure is $-7,5184$. Conclusion: There is differences of blood pressure before and after consuming fish oil. Blood pressure after eating fish oil is lower than before eating fish oil.
\end{abstract}

Keywords: Fish oil, omega-3 fatty acid, blood pressure.

\section{INTRODUCTION}

Currently degenerative and cardiovascular disease is already one of the health problems of Indonesian society. The results of the Household Health Survey 1972, 1986, and 1992 showed a marked increase in the prevalence of cardiovascular disease as a cause of death. Since 1993, cardiovascular disease is thought to be the number one cause of death. One of the factors that cause the disease is hypertension. ${ }^{1}$ Globally, hypertension is one of the leading causes of death. Blood vessel problems caused by hypertension can cause coronary heart disease, myocardial infarction, stroke, and renal failure. Complications of hypertension in organs such as the heart and kidneys cause a high mortality rate. Complications of hypertension cause patients, families and countries should spend more on treatment and maintenance costs and reduce the quality of life of patients. ${ }^{2}$

Antihypertensive drugs will increase maintenance costs and cause adverse side effects. In addition, treatment of hypertension can not eliminate all the risk of cardiovascular disease associated with an increase in blood pressure. Therefore, modification of living habits becomes an option in overcoming the occurrence of hypertension.$^{3}$ Hypertension is heavily influenced by lifestyle in addition to other factors such as stress, obesity and so on. This lifestyle factor 
is one of the causes of regulated hypertension, unlike heredity, sex, and age. In addition to treatment therapy for people with hypertension, a healthy lifestyle is also able to prevent the onset of hypertension. ${ }^{4}$ Treatment without drugs for hypertensive patients is a healthy diet, lose weight, exercise regularly, relieve emotional stress, stop smoking and not drink alcohol. ${ }^{4}$

The habit of consuming fish oil according to the results of several studies have health benefits, especially heart. Based on research, consumption of fish oil supplements on a regular basis can decrease electrical instability in the heart, especially in patients who suffer from heart rate disorders or rhythm. Increased consumption of fish or fish oil has an impact on reducing the risk of death from heart attacks. ${ }^{5}$

Fish oil is an essential oil intake that contains many of the essential nutrients needed by the human body. In fish oil supplements usually contain fatty acid-rich benefits such as omega-3 fatty acids, eicosapentanoic acid (EPA), and docosahexanoic acid (DHA). ${ }^{6}$ Fish actually do not produce these fatty acids such as herring and sardines, but are obtained from the microalgae consumed by the fish. ${ }^{7}$

Antihypertensive effects and protective effects on strokes have been found in decosahexanoic acid (DHA). DHA is one of the major components in omega-3 unsaturated fatty acids. ${ }^{8} \mathrm{~A}$ number of new evidence have suggested that eicosapentanoic acid (EPA, 20: $5 \omega 3$ ) and DHA, docosahexanoic acid ( 22: $6 \omega 3$ ) have different effects on lipids and lipoproteins, blood pressure, pulse rate, and vascular reactivity. ${ }^{3}$

Various studies on the effects of fish oil on blood pressure have been widely practiced, one of which is a study conducted by Morris et al. in 1993 against 1356 people who consumed omega- 3 fatty acids with an average of $4.8 \mathrm{~g} /$ day. Morris et al. found that there was a drop in blood pressure of $1.5-3.0 \mathrm{mmHg}$ in people taking omega-3 fatty acids.

The most potent hypotension effects were mainly in the hypertensive group group with a decrease in blood pressure of $2.0-3.4 \mathrm{mmHg}$, and not significantly in the normotensive group with a drop in blood pressure of $0.4-0.7 \mathrm{mmHg}$. In research conducted by Appel et al. 1993 showed a reduction in blood pressure of 0.5 -
$1 \mathrm{mmHg}$ in the normotensive group and 5.3-5.5 $\mathrm{mmHg}$ in the untreated hypertension group with an average omega- 3 fatty acid consumption of more than 3 grams / day. In addition to the usefulness of fish oil in preventing cardiovascular disease, fish oil also has other benefits such as treating rheumatoid arthritis, depression, anxiety, anticancer especially breast cancer and prostate cancer, improving immune function in children, and improving brain health. ${ }^{9}$

Based on the theoretical information that has been described, the authors are interested to conduct research on the difference in blood pressure before and after eating fish oil. This study is expected to provide information to the public in an effort to maintain health, especially in the prevention of cardiovascular disease. The purpose of this study was to analyze differences in blood pressure before and after consuming fish oil in FKG UNPAD students.

\section{METHODS}

This research was conducted by quasi experimental method (quasi experimental). In accordance with the purpose of research is to prove the difference in blood pressure before and after eating fish oil (fish oil). Population in this research is preclinical student of Faculty of Dentistry Universitas Padjadjaran in Jatinangor.

The criteria of the population are determined as follows: the preacher is a preclinical student of Dentistry Faculty of Padjadjaran University, male or female, 18-25 years old, general condition and healthy body condition, not consuming medicines that can affect blood pressure and pulse, not consuming alcohol, not smoking, not in a state of pregnancy or menstruation, and willing to be naracoba in this study.

Sampling in this study as many as 30 people naracoba by using purposive sampling method. The tools and materials used in this research are Sphygmomanometer, stethoscope, fish oil, plastic medicine bag, questionnaire sheet, check sheet, informed consent form.

The study was conducted on 30 FKG UNPAD students who met the population criteria. Procedure Research is as follows research done on the morning for three days, before naracoba doing activity, naracoba are welcome to sit and 
fill Informed Consent sheet, blood pressure measurement done on the first day in the morning before mengonsumi fish oil for two days. Measurements taken three times, then taken

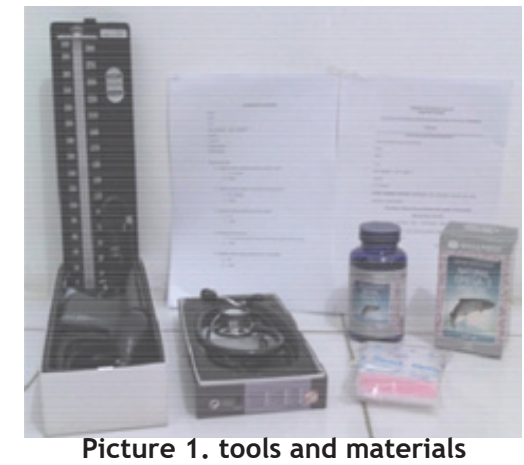

average, naracoba given fish oil as much as 8 capsules for two days. Naracoba was instructed to consume fish oil twice a day each two capsules, the second day naracoba instructed to consume fish oil that has been given according to the dosage, blood pressure measurement done on the third day in the morning after consuming fish oil for two days. The measurement is done three times, then the average is taken. The Blood Pressure Measurement Procedure is naracoba sitting with the arms bent over the table forming a $45^{\circ}$ angle with the chest, the arm not in a twisted state or pinned sleeve, the cuff is mounted with the cuffs bottom 2-3 cm from the cubiti fossa and equal to the heart, the area the radial artery is palpated and the cuff is pumped until the radial pulse pulse is not palpable, the pressure inside the cuff is raised to $20-30 \mathrm{mmHg}$, then the pressure is lowered slowly at a rate of $2-3 \mathrm{mmHg}$ per second subtly and not stagnant.

Systolic pressure is set according to the first pulsed pulse in the radial artery area, the stethoscope is placed in the brachial artery area and the cuff is pumped up to $20-30 \mathrm{mmHg}$ above the systolic pressure obtained from the preceding procedure, the pressure inside the cuff is lowered slowly at a rate of $2-3 \mathrm{mmHg}$ per second subtly and not stagnantly, the systolic pressure is set according to Phase 1 Korotkoff sound, where pulsation in the artery brakhialis, when the pressure is on in the cuff is lowered, the pulsation becomes dim or no longer heard. It was defined as diastolic pressure and referred to as Korotkoff $\mathrm{V}$, and the last measurement of blood pressure was performed three times, recorded the results to determine the mean.

\section{RESULTS}

Tabel 1. Average Blood Pressure Before and After Consuming Fish Oil

\begin{tabular}{|c|c|c|c|c|c|c|c|}
\hline \multicolumn{4}{|c|}{ Press Blood Sistolik (mmHg) } & \multicolumn{4}{|c|}{ Press Blood Diastolik (mmHg) } \\
\hline \multicolumn{2}{|c|}{ Before } & \multicolumn{2}{|c|}{ After } & \multicolumn{2}{|c|}{ Before } & \multicolumn{2}{|c|}{ After } \\
\hline \multicolumn{2}{|c|}{ Average standard deviation } & \multicolumn{2}{|c|}{ Average standard deviation } & \multicolumn{2}{|c|}{ Average standard deviation } & \multicolumn{2}{|c|}{ Average standard deviation } \\
\hline $\bar{x}$ & $S_{b}$ & $\bar{x}$ & $S_{b}$ & $\bar{x}$ & $S_{b}$ & $\bar{x}$ & $S_{b}$ \\
\hline 115,6 & 10,1839 & 109,8889 & 9,0821 & 80,7667 & 7,4593 & 76,6778 & 5,8555 \\
\hline
\end{tabular}

This study was conducted on 30 people naracoba by measuring blood pressure (systolic and diastolic) before and after eating fish oil (fish oil). The mean value of naracoba blood pressure before and after consuming fish oil is presented in Table 1 , while statistical analysis is presented in Table 2. Table 1 shows the mean systolic pressure before consuming fish oil of $115.6 \mathrm{mmHg}$ with standard deviation of 10.1839 and after consuming fish oil of 109.8889 with standard deviation of 9.0821 .

Average diastolic pressure before consuming fish oil equal to $80,7667 \mathrm{mmHg}$ with standard deviation of 7,4593 and after consuming fish oil equal to 76,6778 with standard deviation equal to
5,8555 . To better see the drop in blood pressure, more is presented in Figure 2. Figure 2 Average Blood Pressure Before and After Consuming Fish Oil Having obtained the average blood pressure before and after eating fish oil, it can be searched differences in mean values, standard deviation, and $t$ arithmetic blood pressure before and after eating fish oil. The results of these calculations can be seen in Table 2 .

Table 2 shows the difference of mean value of systolic pressure before and after consuming fish oil equal to -5.7111 with standard deviation 2,4176 and based on statistical analysis got $t$ count equal to $-12,9389$. Differences in mean values of 
diastolic pressure before and after consuming fish oil equal to -4.0889 with standard deviation 2.9788 and based on statistical analysis obtained $t$ count equal to $-7,5184$. The results were calculated statistically by using paired data t test.

The hypothesis for testing blood pressure is Ho: B 0; There was no difference in blood pressure before and after consuming fish oil and $\mathrm{H} 1$ : B0; There is a difference in blood pressure before and after consuming fish oil. Ho is rejected

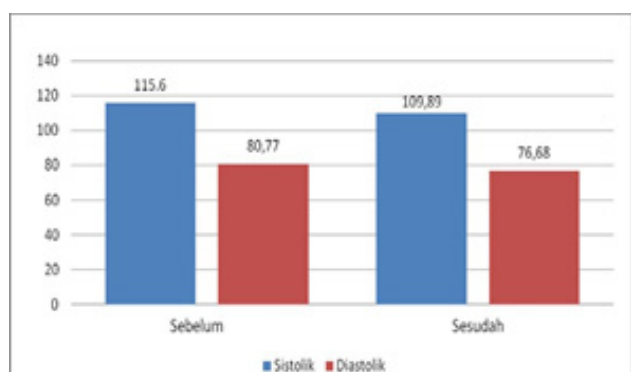

Gambar 2 Rata-rata Tekanan Darah Sebelum dan Sesudah Mengonsumsi Minyak Ikan (Fish Oil)

Tabel 2. Differences in Mean Blood Pressure Value Before and After Consuming Fish Oil

\begin{tabular}{ccccc}
\hline No & Measurment & Different & $\begin{array}{c}\text { standard } \\
\text { deviation }\end{array}$ & t-count \\
& $\bar{B}$ & $S_{b}$ & \\
\hline 1 & $\begin{array}{c}\text { Press Blood } \\
\text { Sistolik }\end{array}$ & $-5,7111$ & 2,4176 & $-12,9389$ \\
2 & $\begin{array}{c}\text { Press Blood } \\
\text { Sistolik }\end{array}$ & $-4,0889$ & 2,9788 & \\
\hline
\end{tabular}

if the test criteria thitung ttabel, otherwise $\mathrm{H} 1$ accepted. ttable is obtained from the distribution list $\mathrm{t}$ with $\mathrm{dk}(\mathrm{n}-1)$ and probability (1-1 / 2a). Based on statistical analysis using paired test data formula $(\mathrm{t})$ got result $\mathrm{t}$ systolic count $=-12,9389$ and $\mathrm{t}$ count diastolik $=-7,5184$. Test criteria at significance level $a=0.05$; obtained $t$ thitung ttable t $(0.975 ; 29) 2$, 04; means, thitung systolic $>$ ttable and thitung diastolic $>$ ttable, sehinggan Ho hypothesis rejected and hypothesis $\mathrm{H} 1$ accepted.

\section{DISCUSSION}

Based on the results of research that has been done on blood pressure before and after consuming fish oil, obtained t count 12,9389 for systolic blood pressure and thitung 7, 5184 for diastolic blood pressure. This result in absolute form is greater than ttable that is equal to 2.04. This means that there is a difference in blood pressure before and after eating fish oil. Blood pressure after eating fish oil decreased.

The decrease in systolic blood pressure after consuming fish oil from an average of $115.6 \mathrm{mmHg}$ to $109.8889 \mathrm{mmHg}$ and decreased diastolic blood pressure after eating fish oil from an average of $80.7667 \mathrm{mmHg}$ to $76.6778 \mathrm{mmHg}$.

Blood pressure always changes daily between 20-30 mmHg. The mean decrease in systolic blood pressure of $5.7111 \mathrm{mmHg}$ and decreased mean diastolic blood pressure was $4.0889 \mathrm{mmHg}$. The drop in blood pressure within normal limits is due to the age factor. Research samples aged between 18-25 years are physiologically in an optimal phase so that blood pressure can be controlled by the physiological reflex in the cardiovascular system (Guyton dan Hall, 1996).10

Fish oil consumed proven to lower blood pressure. This is related to the amount of fish oil consumed. Fish oil should be consumed in doses high enough to produce the desired effect. The amount of fish oil that is effective for lowering blood pressure is more than 3 grams per day.

Some of the contents of fish oil efficacious lowering blood pressure. The content of omega-3 fatty acids are very high in fish oil causes fish oil has the effect of lowering blood pressure. Omega-3 fatty acids are long-chain saturated fatty acids or Polyunsaturated Fatty Acids (PUFAs). Omega-3 PUFAs contain eicosapentanoic acid (EPA) and docosahexanoic acid (DHA) (Lee and Lip, 2003).11

The effect of EPA and DHA on blood pressure decreases is to improve the function of blood vessels by increasing blood vessel relaxation and nitric oxide synthesis, suppression of thromboxane A2 production that increases platelet aggregation and vasoconstriction, increased prostacyclin production such as PGI2 inhibiting platelet aggregation and increasing vasodilation, plasma noradrenaline and increase ATP (Whelton et al, 2003).3 The results showed that there were significant differences in blood pressure between before and after consuming fish oil.

\section{CONCLUSION}

There is differences of blood pressure before and after consuming fish oil. Blood pressure after eating fish oil is lower than before eating fish oil. 


\section{REFERENCES}

1. Armilawaty, Amalia $\mathrm{H}$, Amiruddin $\mathrm{R}$. Hipertensi dan faktor resikonya dalam kajian epidemiologi. New paradigm for public health. 2007 .

2. Depkes RI. InaSH menyokong penuh penanggulangan hipertensi. Jakarta: Depkes RI. 2007.

3. Bruno $C M$, Amaradio MD, Pricoco G, Marino E, Bruno F. Lifestyle and Hypertension: An Evidence-Based Review. J Hypertens Manag. 2018;4(1):1-10. DOI: 10.23937/2474$3690 / 1510030$

4. Puspitorini M. Hipertensi, Cara Mudah Mengatasi Tekanan Darah Tinggi. Yogyakarta : Image Press. 2008. 53 pp.

5. Continuing Profesional Development Dokter Indonesia, Minyak ikan stabilkan jantung. 2008.
6. Breslow JL. n-3 fatty acids and cardiovascular disease. Am J Clin Nutr. 2006 Jun;83(6 Suppl):1477S-1482S. doi: 10.1093/ ajcn/83.6.1477S.

7. Sears B. The Omega R-X Zone: The Miracle of The New High-Dose Fish Oil. USA : HarperCollins Publisher Inc. 2002. 31-39, 9094, 106-113, 203-206 pp.

8. Kaplan MN. Kaplan's Clinical Hypertension 8th edition. Texas : Lippincott Williams \& Wilkins Publishers. 2002.

9. Farooqui AA. Beneficial Effect of Fish Oil in Human Brain. New York : Springer Science. 1-16. 2009.

10. Guyton CA, Hall JE. Buku Ajar Fisiologi Kedokteran $9^{\text {th }}$ Ed. Jakarta : EGC. 1996. 137, 205-215 pp.

11. Lee WK, Lip HYG. The role of omega-3 fatty acids in the second prevention of cardiovascular disease. Q J Med. 2003;96(5):465-80 pp. 